Table 1. EFFnct of PHenyuatanine on Transport of AMuno-acids

\begin{tabular}{|c|c|c|c|}
\hline \multirow[b]{2}{*}{ Amino-acid } & \multicolumn{2}{|c|}{$\begin{array}{c}\text { Concentration difference developed } \\
\text { between slices and suspending } \\
\text { medium (mM) }\end{array}$} & \multirow{2}{*}{$\begin{array}{l}\text { Inhibition } \\
\text { by } \\
\text { L-phenyl- } \\
\text { alanine } \\
\text { (per cent) }\end{array}$} \\
\hline & $\begin{array}{l}\text { When present } \\
\text { alone }\end{array}$ & $\begin{array}{l}\text { In the presence } \\
\text { of an equimolar } \\
\text { amount of } \\
\text { L-phenylalanine }\end{array}$ & \\
\hline L-Proline & $8 \cdot 48 \pm 0.73$ & $7 \cdot 71 \pm 0.67$ & 9 \\
\hline $\mathrm{L}_{\mathrm{H}}$-Histidine & $15 \cdot 6 \underset{\left(1 \frac{1}{2}\right)}{ \pm} 1 \cdot 1$ & $9 \cdot 0 \frac{ \pm}{(20)} 1 \cdot 6$ & 42 \\
\hline L-Arginine & $2 \cdot 70 \pm 0.56$ & $1.47 \pm 0.32$ & 46 \\
\hline L-Ornithine & $3.44 \pm 0.31$ & $1.82 \pm 0.14$ & 47 \\
\hline L-Tyrosine & $3 \cdot 88 \pm 0.32$ & $\begin{array}{c}1 \cdot 15 \pm 0 \cdot 10 \\
(12)\end{array}$ & 70 \\
\hline
\end{tabular}

Initial concentration of each amino-acid in suspending medium $2 \mathrm{mM}$. Figures shown for concentration difference are mean and Experimental period, $1 \mathrm{hr}$. $37^{\circ} \mathrm{C}$.

acids in brain and other tissues of the body. The considerable interference with tyrosine transport would be of greater significance in those tissues such as brain and intestinal mucosa which transport tyrosine the most actively'. With tissues in which there does not appear to be active transport of tyrosine $\theta^{8}$, movement of tyrosine would probably not be affected, as has already been shown with liver ${ }^{10}$.

I wish to thank Prof. N. L. Edson for giving me facilities in the Department of Biochemistry, and the Medical Research Council of New Zealand for financial support.

Department of Medicine,

K. D. NeAME* Medical School,

Great King Street,

Dunedin, New Zealand.

- Present address: Department of Physiology, University of Liverpool, England.

${ }_{1}$ Knox, W. E., and Hsia, D. Y.-Y., Amer. $J$, Med., 22, 687 (1957).

2 Meister, A., Pediatrics, 21, 1021 (1958).

Christensen, H. N., Riggs, T. R., Fischer, H., and Palatine, I. M., J. Biol. Chem., 198, 1 (1952).

- Wiseman, G. and Ghadially, F. N., Brit. J. Cancer, 9, 480 (1955).

5 Neame, K. D., J. Neurochem., 6, 358 (1961).

'Chinard, F. P., J. Biol. Chem., 199, 91 (1952).

"Macpherson, H. T., Biochem. J., 40, 470 (1946).

${ }^{8}$ Ceriotti, G., and Spandrio, L., Biochem. J., 66, 607 (1957).

- Neame, K. D., Proc. Univ. Otago Med. Sch., 39, 11 (1961)

${ }^{10}$ Bickis, I. J., Kennedy, J. P., and Quastel, J. H., Nature, 179, 1124 (1957).

\section{Stability of Dextran during Prolonged Storage}

So far as we are aware, no measurements relating to the stability of clinical dextran solutions kept for several years have been published. Two dextran solutions made in the United States, $A$ and $B$, and two made in Great Britain, $C$ and $D$, were examined in 1954, and again after storage for $5 \mathrm{yr}$. at $4^{\circ} \mathrm{C}$. Where applicable the methods of testing described in the British Pharmacopœia were used. The optical rotation of each dextran was determined and used in calculating the concentrations of solutions for the viscosity measurements (Table 1). Dextran $D$ had undergone the most change; the changes in the others were relatively small.

The renal excretion of these dextrans was measured in rabbits (Table 2). The greater part of the dextran

\begin{tabular}{cccc}
\multicolumn{3}{c}{ Table 1 } \\
Dextran & Optical rotation & Intriasic viscosity at $25^{\circ} \mathrm{C}$. \\
& $(a)$ & 1954 & 1959 \\
$\boldsymbol{A}$ & $195 \cdot 1$ & $0 \cdot 249$ & $0 \cdot 248$ \\
$B$ & $197 \cdot 7$ & $0 \cdot 254$ & $0 \cdot 251$ \\
$\boldsymbol{B}$ & $201 \cdot 2$ & $0 \cdot 394$ & 0.388 \\
$D$ & $198 \cdot 1$ & 0.362 & 0.326
\end{tabular}

was excreted on the first day, less than 3 per cent on the second and less than 1 per cent on the third day. Two, three or four rabbits were used for each determ. ination and the daily results averaged; Table 2 records the totals for 3 days after injection. The results for dextran $A$ suggest a change in molecular composition, but no corroboration of this was found in the other measurements.

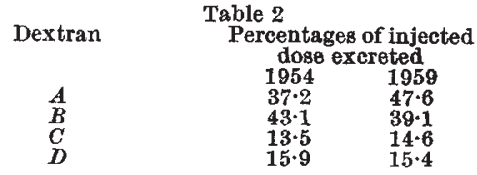

The retention of each dextran in the plasma was determined by taking the average of daily estimations in the same groups of rabbits (Table 3). During five years of storage little if any change had occurred in the dextrans affecting their retention in the circulation.

Table 3. Plasma Concentration of Dextran as Peroentage of CONOWNTRATION 10 MIN. AFTER INJECTION

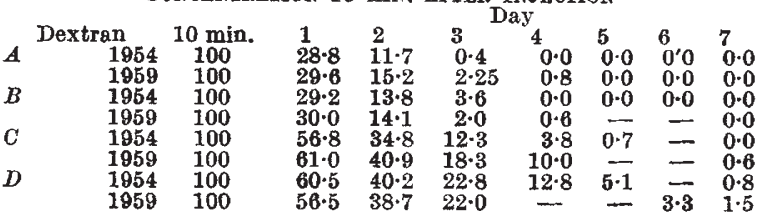

The difference in molecular composition of American and British dextrans is well illustrated by these results. The lower average molecular weight of the American dextrans is associated with shorter retention in the circulation and greater renal excretion. The British dextran, of higher average molecular weight, would induce greater aggregation of red cells in vitro ${ }^{2}$ and possibly in vivo, too.

From our observations we conclude that during the 5-yr. period there was little, if any, change in the molecular composition of these dextran solutions and none that would be noticeable in elinical use. It is probable that any limitation of the storage 'life' of dextran solution will be imposed by defects in the container and its closure rather than by any instability of dextran solution itself.

Lister Institute, Eistree.

$$
\text { W. D'A. MaYCoCK }
$$

Medical Research Council Industrial Injuries

and Burns Research Unit,

Accident Hospital, Birmingham.

- British Pharmacopocia (1958).

${ }^{2}$ Hardwicke, J., Ricketts, C. R., and Squire, J. A., Nature, 166, 988 (1950).

\section{PHARMACOLOGY}

\section{Effects of 7-Chloro-2-methylamino-5- phenyl-3H-I,4-benzodiazepin-4-oxide on Mitochondria from Rat Liver and Brain}

Axthough little is known about the relations between in vivo drug action and the effects of a drug on metabolic processes in vitro, it has been confirmed that psychopharmacological materials in many cases act on oxidative reactions in the mitochondrial respiratory chain. The two different drugs, amytal and chlorpromazine, both, for example, have inhibi- 